Check for updates

Cite this: RSC Adv., 2017, 7, 45401

Received 10th August 2017

Accepted 19th September 2017

DOI: $10.1039 / c 7 r a 08836 a$

rsc.li/rsc-advances

\section{Sterically bulky amido magnesium methyl complexes: syntheses, structures and catalysis $\uparrow$}

\author{
Mengtao Ma, (D) *a Jia Li, ${ }^{a}$ Xingchao Shen, ${ }^{a}$ Zhijuan $\mathrm{Yu}{ }^{a}$ Weiwei $\mathrm{Yao}^{\mathrm{b}}$ \\ and Sumod A. Pullarkat (D)
}

A series of bulky secondary amines were treated with two equiv. Grignard reagent MeMgl at low temperature to yield the corresponding magnesium methyl complexes (1-4) in high yields. The prepared complexes have been comprehensively characterized. All four complexes exhibited very high reactivity as efficient pre-catalysts in the catalytic hydroboration of ketones with pinacolborane under mild conditions and at low catalyst loadings.

\section{Introduction}

The catalytic hydroboration of unsaturated substrates is an important transformation in organic chemistry. Recently a variety of unsaturated organic compounds such as alkenes, alkynes, imines, aldehydes and ketones have been hydroborated to get the corresponding organoboranes compounds using transition metals and main group compounds as catalysts. ${ }^{1-9}$ Even carbon dioxide could be reduced to a $\mathrm{C}_{1}$-building block such as methanol, formaldehyde and formic acid via the catalytic hydroboration..$^{\mathbf{1 0 1 1}}$ For example, Nozaki et al. reported the reduction of $\mathrm{CO}_{2}$ with $\mathrm{HBpin}$ catalyzed by $\mathrm{N}$-heterocyclic carbene supported $\mathrm{Cu}(\mathrm{I})$ complex $\left[(\mathrm{IPr}) \mathrm{Cu}\left(\mathrm{O}^{\mathrm{t}} \mathrm{Bu}\right)\right]$ recently. ${ }^{\mathbf{1 0}}$

The reduction of carbonyl compounds is a facile and efficient synthetic route to functionalized alcohols which are industrially important compounds that are produced in bulk. Compared to hydrogenation and hydrosilylation protocols, the hydroboration of carbonyl compounds is more efficient and can normally proceed at room temperature and with very low catalyst loading. ${ }^{12-15}$ For instance, quite recently Gade et al. reported that a manganese alkyl complex containing a chiral bis(oxazolinyl-methylidene)isoindoline pincer ligand has been used as a pre-catalyst for the enantioselective hydroboration of ketones under mild reaction conditions. ${ }^{14}$ When compared to the transition metal catalyzed hydroboration of aldehydes and ketones which has been extensively investigated, the research on the catalytic hydroboration of carbonyl compounds using

\footnotetext{
${ }^{a}$ College of Science, Nanjing Forestry University, Nanjing 210037, People's Republic of China.E-mail: mengtao@njfu.edu.cn

${ }^{b}$ College of Pharmacy, Nanjing University of Chinese Medicine, Nanjing 210023, People's Republic of China

'Division of Chemistry \& Biological Chemistry, School of Physical and Mathematical Sciences, Nanyang Technological University, Singapore 637371, Singapore

$\dagger$ CCDC 1554843-1554846. For crystallographic data in CIF or other electronic format see DOI: $10.1039 / \mathrm{c} 7 \mathrm{ra08836a}$
}

main group catalysts is less developed but has recently received considerable attention by many research groups. ${ }^{12-27}$

Compared to the precious and relatively toxic transition metals, amongst the main group metals, magnesium is earthabundant, non-toxic and inexpensive. The Mg-catalyzed hydroboration has been relatively well explored and has shown high reactivity in recent studies. ${ }^{\mathbf{2 8 - 3 5}}$ For example, the Hill group has reported the hydroboration of pyridines, aldehydes, ketones, imines, isonitriles, nitriles, carbodiimides and isocyanates with pinacolborane (HBpin) using the $\beta$-diketiminato magnesium $n$-butyl complex [( $\left.\left.{ }^{\mathrm{Dipp}} \mathrm{Nacnac}\right) \mathrm{Mg}^{n} \mathrm{Bu}\right]$ as an efficient pre-catalyst. ${ }^{29}$ Harder et al. found that the $\beta$-diketiminato magnesium hydride tetramer also could be used as a catalyst in the catalytic hydroboration of pyridines. ${ }^{30}$ Hydroboration of esters to two alkoxyborates was successfully achieved using a tris(pyrazolyl) borate magnesium methyl complex as a catalyst by Sadow and co-workers. The same catalyst can also catalyze the hydroboration of amides for their deoxygenation to amines. ${ }^{31}$ However, literature reports about the Mg-catalyzed hydroboration of ketones are relatively few and the catalysts are mainly the corresponding bidentate $\beta$-diketiminato, metalorganic framework and ion pair magnesium complexes respectively. ${ }^{29 c, 32-34}$ Herein we reported the syntheses and characterizations of a series of bulky secondary amidomagnesium methyl complexes which can act as new monodentate magnesium pre-catalysts for the hydroboration of a range of ketones.

\section{Results and discussion}

\section{Syntheses and structures of magnesium methyl complexes}

The bulky secondary amine $\operatorname{ArNH}\left(\mathrm{SiPh}_{3}\right) \quad\left(\mathrm{Ar}=\mathrm{C}_{6} \mathrm{H}_{2}\right.$ $\left.\mathrm{Me}\left(\mathrm{CHPh}_{2}\right)_{2}-4,2,6\right)$ was treated with one equiv. MeMgI in $\mathrm{Et}_{2} \mathrm{O}$ or THF, we initially attempted to prepare the corresponding magnesium iodide complex, namely the precursor of the magnesium(I) complex. During the process of this work Jones et al. published the corresponding magnesium(I) complexes. ${ }^{36}$ 
However, an intractable mixture was observed. According to the ${ }^{1} \mathrm{H}$ NMR spectroscopic analysis of the obtained white solid, we ascertained that the corresponding magnesium iodide and magnesium methyl complexes could be in the mixture because there are two sets of new peaks in the ${ }^{1} \mathrm{H}$ NMR spectrum of the solid mixture besides signals that can be attributed to the ligand. Furthermore, a new singlet signal at $\delta-1.60 \mathrm{ppm}$ was also observed which could be the characteristic methyl group resonance because the previously reported magnesium methyl complexes have also shown the similar high field signal characteristic of the magnesium bound methyl from -0.65 to $-2.00 \mathrm{ppm}$ in ${ }^{1} \mathrm{H}$ NMR spectra. ${ }^{37-39}$ We reasoned that when the amido ligand was treated with MeMgI, firstly the corresponding magnesium iodide was produced. However due to the high reactivity of the iodide moiety it further reacted with MeMgI to yield the magnesium methyl complex. In order to prove our speculation, the same ligand $\mathrm{ArNH}\left(\mathrm{SiPh}_{3}\right)$ was treated with two equiv. Grignard reagent MeMgI and the corresponding magnesium methyl complex 1 was indeed obtained as colorless crystals in high yield (88\%) (Scheme 1). ${ }^{1} \mathrm{H}$ NMR spectroscopic analysis further revealed that the NH signal $(\delta=2.68 \mathrm{ppm})^{\mathbf{4 0}}$ of the starting material disappeared, with the subsequent appearance of a new singlet signal at $\delta-1.60 \mathrm{ppm}$ which is assigned to the $\mathrm{Mg}-\mathrm{CH}_{3}$ characteristic resonance in 1 . The ${ }^{13} \mathrm{C}$ $\left\{{ }^{1} \mathrm{H}\right\}$ NMR spectrum of complex 1 further confirmed our speculation. It also displayed a characteristic high field $\mathrm{Mg}-\mathrm{CH}_{3}$ resonance at $\delta-\mathbf{1 4 . 5} \mathrm{ppm}$ as observed in similar magnesium methyl complexes. ${ }^{37-39}$ In the ${ }^{29} \mathrm{Si}\left\{{ }^{1} \mathrm{H}\right\}$ NMR spectrum of complex 1 the $\mathrm{SiPh}_{3}$ signal $(\delta=-18.8 \mathrm{ppm})$ of the starting secondary amine $\operatorname{ArNH}\left(\mathrm{SiPh}_{3}\right)$ disappeared and a new singlet signal at $\delta-26.4 \mathrm{ppm}$ was found which is similar to analogous magnesium $n$-butyl complex $(\delta=-24.7 \mathrm{ppm}) \cdot{ }^{36}$ Finally, single crystal X-ray diffraction, NMR and CHN analysis confirmed the successful synthesis of $\mathbf{1}$.

When the similar secondary amines $\mathrm{Ar}^{*} \mathrm{NH}\left(\mathrm{SiPh}_{3}\right)\left(\mathrm{Ar}^{*}=\mathrm{C}_{6}\right.$ $\left.\mathrm{H}_{2}{ }^{\mathrm{i}} \operatorname{Pr}\left(\mathrm{CHPh}_{2}\right)_{2}-4,2,6\right), \operatorname{ArNH}\left(\mathrm{SiMe}_{3}\right)$ or $\operatorname{DippNH}\left(\mathrm{SiMe}_{3}\right)(\mathrm{Dipp}=$ 2,6-diisopropylphenyl) were treated with one equiv. MeMgI respectively, unfortunately the intractable mixtures were once again obtained which consisted of the corresponding magnesium

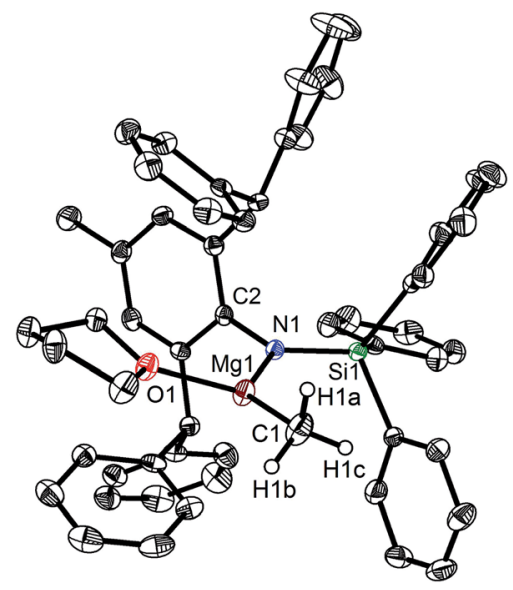

Fig. 1 Molecular structure of 1.

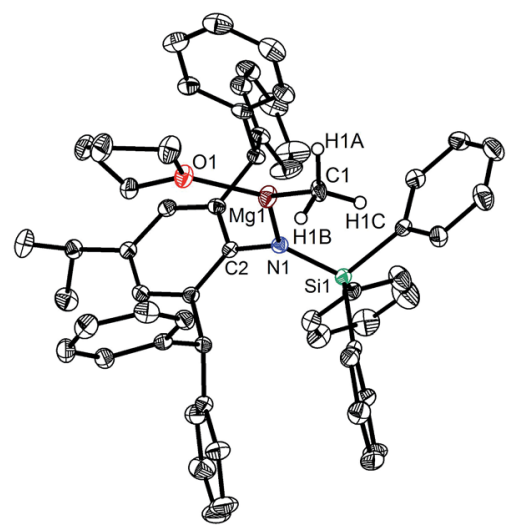

Fig. 2 Molecular structure of 2.

iodide, methyl complexes and ligands etc. As expected, the reaction between the secondary amines and two equiv. MeMgI also produced the corresponding magnesium methyl complexes 2-4 in high yield as seen earlier in the case of complex 1 . The high field $\mathrm{Mg}-\mathrm{CH}_{3}$ characteristic resonances of complexes 2-4 were<smiles>[R]c1cc(C(c2ccccc2)c2ccccc2)c(N[AsH3])c(C(c2ccccc2)c2ccccc2)c1</smiles><smiles>[R]c1cc(C(c2ccccc2)c2ccccc2)c(N([AsH2])[C@H](C)CCCCC)c(C(c2ccccc2)c2ccccc2)c1</smiles>

$\mathrm{R}=\mathrm{Ph}, \mathrm{R}^{\prime}=\mathrm{Me}, \mathrm{n}=1$ (1)

$\mathrm{R}=\mathrm{Ph}, \mathrm{R}^{\prime}={ }^{\mathrm{i}} \mathrm{Pr}, \mathrm{n}=1$ (2)

$\mathrm{R}=\mathrm{Me}, \mathrm{R}^{\prime}=\mathrm{Me}, \mathrm{n}=2$ (3)
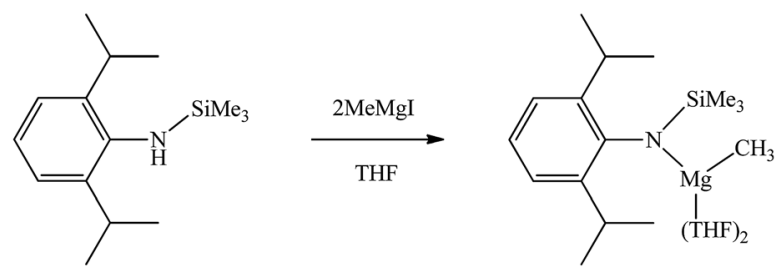

(4)

Scheme 1 Syntheses of complexes 1-4. 


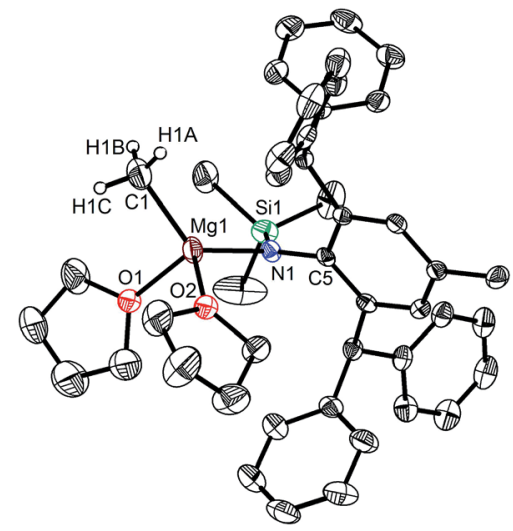

Fig. 3 Molecular structure of 3 .

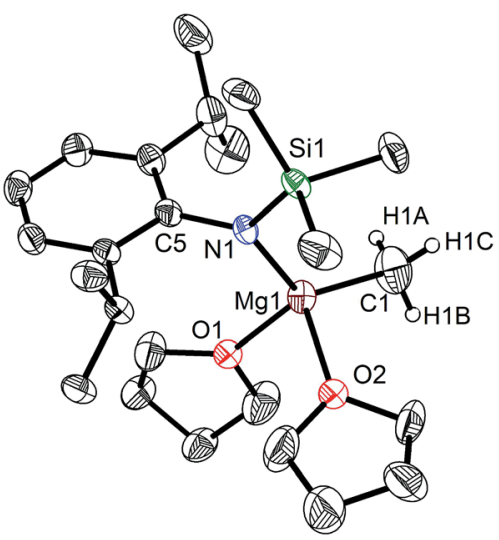

Fig. 4 Molecular structure of 4

Table 1 Selected bond lengths $[\AA ̊]$ and angles $\left[{ }^{\circ}\right]$ for 1

\begin{tabular}{llll}
\hline $\mathrm{Mg}(1)-\mathrm{C}(1)$ & $2.114(4)$ & $\mathrm{Mg}(1)-\mathrm{N}(1)$ & $1.997(3)$ \\
$\mathrm{Mg}(1)-\mathrm{O}(1)$ & $2.010(2)$ & $\mathrm{N}(1)-\mathrm{C}(2)$ & $1.421(4)$ \\
$\mathrm{N}(1)-\mathrm{Si}(1)$ & $1.704(2)$ & & \\
$\mathrm{N}(1)-\mathrm{Mg}(1)-\mathrm{C}(1)$ & $132.34(13)$ & $\mathrm{O}(1)-\mathrm{Mg}(1)-\mathrm{C}(1)$ & $106.09(12)$ \\
$\mathrm{N}(1)-\mathrm{Mg}(1)-\mathrm{O}(1)$ & $116.45(10)$ & $\mathrm{Si}(1)-\mathrm{N}(1)-\mathrm{Mg}(1)$ & $121.77(14)$ \\
$\mathrm{C}(2)-\mathrm{N}(1)-\mathrm{Si}(1)$ & $123.0(2)$ & $\mathrm{C}(2)-\mathrm{N}(1)-\mathrm{Mg}(1)$ & $115.07(18)$
\end{tabular}

Table 2 Selected bond lengths $[\AA]$ and angles $\left[{ }^{\circ}\right]$ for 2

\begin{tabular}{llll}
\hline $\mathrm{Mg}(1)-\mathrm{C}(1)$ & $2.1844(16)$ & $\mathrm{Mg}(1)-\mathrm{N}(1)$ & $1.9973(12)$ \\
$\mathrm{Mg}(1)-\mathrm{O}(1)$ & $2.0123(12)$ & $\mathrm{N}(1)-\mathrm{C}(2)$ & $1.4141(18)$ \\
$\mathrm{N}(1)-\mathrm{Si}(1)$ & $1.7056(12)$ & & \\
$\mathrm{N}(1)-\mathrm{Mg}(1)-\mathrm{C}(1)$ & $130.89(6)$ & $\mathrm{O}(1)-\mathrm{Mg}(1)-\mathrm{C}(1)$ & $107.07(5)$ \\
$\mathrm{N}(1)-\mathrm{Mg}(1)-\mathrm{O}(1)$ & $115.94(5)$ & $\mathrm{C}(2)-\mathrm{N}(1)-\mathrm{Mg}(1)$ & $112.43(9)$ \\
$\mathrm{Si}(1)-\mathrm{N}(1)-\mathrm{Mg}(1)$ & $122.55(7)$ & $\mathrm{C}(2)-\mathrm{N}(1)-\mathrm{Si}(1)$ & $125.00(9)$ \\
\hline
\end{tabular}

observed as singlets at $\delta-1.47,-0.79,-0.94 \mathrm{ppm}$ in the ${ }^{1} \mathrm{H}$ NMR spectra and at $\delta-14.4,-12.6,-15.0 \mathrm{ppm}$ in the ${ }^{13} \mathrm{C}\left\{{ }^{1} \mathrm{H}\right\}$ NMR spectra respectively. These chemical shift values are similar to those of the previously reported magnesium methyl and analogous magnesium butyl complexes. ${ }^{36-39}$ The solid state structure of
Table 3 Selected bond lengths $[\AA]$ and angles $\left[^{\circ}\right]$ for 3

\begin{tabular}{llll}
\hline $\mathrm{Mg}(1)-\mathrm{C}(1)$ & $2.173(4)$ & $\mathrm{Mg}(1)-\mathrm{N}(1)$ & $2.046(2)$ \\
$\mathrm{Mg}(1)-\mathrm{O}(1)$ & $2.065(2)$ & $\mathrm{Mg}(1)-\mathrm{O}(2)$ & $2.038(2)$ \\
$\mathrm{N}(1)-\mathrm{C}(5)$ & $1.410(3)$ & $\mathrm{N}(1)-\mathrm{Si}(1)$ & $1.709(2)$ \\
$\mathrm{N}(1)-\mathrm{Mg}(1)-\mathrm{C}(1)$ & $130.21(11)$ & $\mathrm{O}(1)-\mathrm{Mg}(1)-\mathrm{C}(1)$ & $102.14(11)$ \\
$\mathrm{N}(1)-\mathrm{Mg}(1)-\mathrm{O}(1)$ & $111.21(10)$ & $\mathrm{O}(2)-\mathrm{Mg}(1)-\mathrm{C}(1)$ & $107.08(12)$ \\
$\mathrm{O}(2)-\mathrm{Mg}(1)-\mathrm{N}(1)$ & $105.02(8)$ & $\mathrm{O}(2)-\mathrm{Mg}(1)-\mathrm{O}(1)$ & $96.02(9)$ \\
$\mathrm{C}(5)-\mathrm{N}(1)-\mathrm{Si}(1)$ & $124.55(15)$ & $\mathrm{C}(5)-\mathrm{N}(1)-\mathrm{Mg}(1)$ & $119.36(15)$ \\
$\mathrm{Si}(1)-\mathrm{N}(1)-\mathrm{Mg}(1)$ & $115.01(10)$ & & \\
& & &
\end{tabular}

Table 4 Selected bond lengths $[\AA]$ and angles $\left[{ }^{\circ}\right]$ for 4

\begin{tabular}{llll}
\hline $\mathrm{Mg}(1)-\mathrm{C}(1)$ & $2.129(4)$ & $\mathrm{Mg}(1)-\mathrm{N}(1)$ & $2.019(2)$ \\
$\mathrm{Mg}(1)-\mathrm{O}(1)$ & $2.052(2)$ & $\mathrm{Mg}(1)-\mathrm{O}(2)$ & $2.072(2)$ \\
$\mathrm{N}(1)-\mathrm{Si}(1)$ & $1.699(2)$ & $\mathrm{N}(1)-\mathrm{C}(5)$ & $1.415(3)$ \\
$\mathrm{N}(1)-\mathrm{Mg}(1)-\mathrm{O}(1)$ & $108.12(10)$ & $\mathrm{O}(1)-\mathrm{Mg}(1)-\mathrm{O}(2)$ & $91.95(10)$ \\
$\mathrm{N}(1)-\mathrm{Mg}(1)-\mathrm{O}(2)$ & $107.76(10)$ & $\mathrm{O}(1)-\mathrm{Mg}(1)-\mathrm{C}(1)$ & $105.15(13)$ \\
$\mathrm{N}(1)-\mathrm{Mg}(1)-\mathrm{C}(1)$ & $127.14(14)$ & $\mathrm{O}(2)-\mathrm{Mg}(1)-\mathrm{C}(1)$ & $100.91(14)$ \\
$\mathrm{C}(5)-\mathrm{N}(1)-\mathrm{Si}(1)$ & $123.07(18)$ & $\mathrm{C}(5)-\mathrm{N}(1)-\mathrm{Mg}(1)$ & $116.91(17)$ \\
$\mathrm{Si}(1)-\mathrm{N}(1)-\mathrm{Mg}(1)$ & $119.08(13)$ & &
\end{tabular}

complexes 2-4 were also determined by single crystal X-ray diffraction. The molecular structures of complexes 1-4 are shown in Fig. 1-4. Selected bond lengths and angles for complexes 1-4 are presented in Tables 1-4. X-ray crystal structure analyses further revealed that complexes 1-4 were monomeric. In complexes $\mathbf{1}$ or $\mathbf{2}$, the geometry of three-coordinated magnesium atom was slightly elongated trigonal planar which the nitrogen atom of amido ligand, oxygen atom of THF solvent and carbon atom of new methyl group occupying three vertices of the planar triangle. However, the geometry of four-coordinated magnesium metal in complexes $\mathbf{3}$ or $\mathbf{4}$ was the slightly distorted tetrahedron because there were two coordinated THF solvents. The magnesium-methyl group [Mg-C(1), 2.114(4)-2.1844(16) $\AA]$ bond lengths in complexes 1-4 are similar to those of the reported magnesium methyl complexes which have been structurally

Table 5 Preliminary catalytic screening results

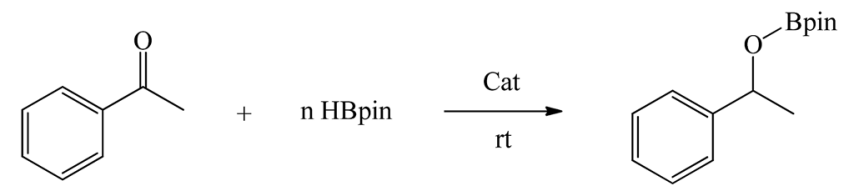

\begin{tabular}{llllll}
\hline Entry & Cat & Cat $(\mathrm{mol} \%)$ & $n$ & Time $(\mathrm{h})$ & Yield $^{a}(\%)$ \\
\hline 1 & $\mathbf{1}$ & 0.1 & 1.5 & 2.5 & 99 \\
2 & 2 & 0.1 & 1.5 & 3 & 99 \\
3 & 3 & 0.1 & 1.5 & 1.5 & 99 \\
4 & 4 & 0.1 & 1.5 & 0.5 & $>99$ \\
5 & 4 & 0.1 & 1 & 2.5 & 98 \\
6 & 4 & 0.5 & 1 & 0.5 & $>99$
\end{tabular}

${ }^{a}$ The reaction was monitored by ${ }^{1} \mathrm{H}$ NMR spectroscopy. 
Table 6 Hydroboration of ketones under the catalysis of the complex 4
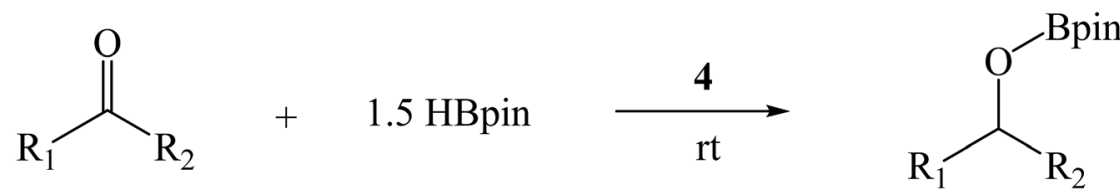

\section{Entry}

$$
\text { Substrate }
$$

Cat (mol\%)

Time (h)

Yield $^{a}(\%)$

1<smiles>CC(=O)c1ccccc1F</smiles><smiles>CC(=O)c1ccc([N+](=O)[O-])cc1</smiles><smiles>CC(=O)c1ccc(C)cc1</smiles><smiles>COc1ccc(C(C)=O)cc1</smiles><smiles>CC(=O)c1ccc(N)cc1</smiles><smiles>CC(C)C(=O)c1ccccc1</smiles><smiles>O=C(c1ccccc1)c1ccccc1</smiles><smiles>CC(=O)c1c(C)cc(C)cc1C</smiles><smiles>CC(=O)C1CCCCC1</smiles>

${ }^{a}$ The reaction was monitored by ${ }^{1} \mathrm{H}$ NMR spectroscopy. ${ }^{b} 60{ }^{\circ} \mathrm{C}$.

characterized. ${ }^{37-39}$ Furthermore when a series of similar amino ligands such as $\mathrm{ArNH}\left(\mathrm{SiMe}_{3}\right)$ and $\mathrm{Ar}{ }^{*} \mathrm{NH}\left(\mathrm{Si}^{i} \mathrm{Pr}_{3}\right)$ were reacted with less reactive Grignard reagent $\mathrm{MeMgBr}$, the corresponding magnesium bromide or methyl complexes could not be isolated.

\section{Catalytic hydroboration of ketones}

Encouraged by the recent success of employing alkaline earth metal complexes as catalysts for the hydroboration of unsaturated molecules ${ }^{\mathbf{1 - 6 2}}$ and with the newly prepared and 
characterised magnesium complexes (1-4) in hand, we initially examined their catalytic activity towards the hydroboration of ketone. In a simple screening reaction, we tested the room temperature catalytic performance of 1-4 when using acetophenone as a test substrate in combination with pinacolborane (HBpin). The results are summarized in Table 5. We found that acetophenone was clearly hydroborated with almost quantitative conversion by 1.5 equiv. of HBpin in the presence of $0.1 \mathrm{~mol} \%$ of complexes 1-4 in few hours (entries 1-4, Table 5). It should be noted that the reactivity of 1-4 is higher than that of the reported $\beta$-diketiminato magnesium $n$-butyl complex $\left[\left({ }^{\text {Dipp }} \mathrm{Nacnac}\right) \mathrm{Mg}^{n} \mathrm{Bu}\right]$ which needed $1 \mathrm{~mol} \%$ catalyst loading and 4 hours to get $94 \%$ conversion in the acetophenone hydroboration. ${ }^{29}$ For complex $\mathbf{4}$, only 30 min was needed at room temperature, other magnesium methyl complexes 1-3 needed a little longer time to achieve near full conversion. It appears that the catalytic activity of 1-4 is in contrast with the steric hindrance associated with their structures. Since complex 4 was noted to be the most active, the HBpin loading was reduced from 1.5 to 1 equiv. However, the hydroboration reaction time was prolonged from 0.5 to $2.5 \mathrm{~h}$ (entry 5, Table 5). When the catalyst loading of 4 was increased from 0.1 to $0.5 \mathrm{~mol} \%$, the reaction time did not decrease appreciably, and still required half an hour for conversion (entry 6, Table 5).

To further extend the utility of the prepared magnesium complexes, we explored the catalytic hydroboration of ketones bearing different functionalities. With 0.1 mol\% of 4 and HBpin as the reductant, the hydroboration of acetophenones with $\mathrm{F}-, \mathrm{O}_{2} \mathrm{~N}-$, NC-, MeO- and $\mathrm{H}_{2} \mathrm{~N}$ - substituents (entries 1-8, Table 6) were completed in very high yield. Since both electrondonating and electron-withdrawing groups appeared to make the hydroboration reaction slightly sluggish, we used a higher catalyst loading $(1 \mathrm{~mol} \%)$ in those instances to shorten the reaction time (entries 4, 6, 8, Table 6). Compared to $4^{\prime}$-nitroacetophenone (entry 2, Table 6), 4'-aminoacetophenone (entry 8 , Table 6) required a slightly longer time possibly because it will react with HBpin leading to the uncatalysed amine-borane blocking catalytic $\mathrm{C}=\mathrm{O}$ hydroboration pathway. ${ }^{41}$ The reaction showed tolerance towards fluoride group which orthosubstituted $\mathrm{F}$ group lead to an increase in reactivity compared to the parent acetophenone (entry 1 , Table 6 ). The incorporation of a cyano group however necessitated the need for a higher catalyst loading ( $1 \mathrm{~mol} \%$ ) to ensure a high conversion in a short time (entries 3 and 4, Table 6). Complex 4 was also active towards more sterically hindered aryl-substituted ketones, although in these cases, a slightly longer reaction time was required to achieve a high yield at room temperature (entries 9 and 10, Table 6). For the benzophenone hydroboration, it showed equal efficiency with the above-mentioned [ $\left({ }^{\mathrm{Dipp}} \mathrm{Nac}-\right.$ nac) $\left.\mathrm{Mg}^{n} \mathrm{Bu}\right]^{29}$ and was slightly faster than the same amide ligand complexes LMH ( $\mathrm{M}=\mathrm{Ge}$ or $\mathrm{Sn}) .{ }^{\mathbf{1 6}}$ However, the hydroboration of the bulky 2,4,6-trimethylacetophenone was slow ( 24 h) even at $60{ }^{\circ} \mathrm{C}$ and required a higher catalyst loading ( $1 \mathrm{~mol} \%$ ) to reach a high conversion (entries 11 and 12, Table 6). This is slightly slower than that of $\left[\left({ }^{\text {Dipp }} \mathrm{Nacnac}\right) \mathrm{Mg}^{n} \mathrm{Bu}\right] .^{29}$ Dialkyl ketones were hydroborated in quantitative yield at room temperature in a short time (entries 13 and 14, Table 6).

\section{Conclusions}

In conclusion, we have successfully prepared a series of new monodentate magnesium methyl complexes via the use of sterically bulky secondary amines and two equiv. MeMgI. The fully characterized complexes were found to be efficient precatalysts for the hydroboration of a variety of aromatic and aliphatic ketones under mild conditions and at low catalyst loadings and showed moderate efficiency on the hydrosilylation of acetophenone. Investigation of the detailed mechanism of the catalytic cycle is in progress in our laboratory.

\section{Experimental section}

All manipulations were carried out using standard Schlenk and glove box techniques under an atmosphere of high purity dinitrogen or argon. Toluene, THF, diethyl ether and hexane were distilled from molten sodium. ${ }^{1} \mathrm{H},{ }^{13} \mathrm{C}\left\{{ }^{1} \mathrm{H}\right\}$ and ${ }^{29} \mathrm{Si}\left\{{ }^{1} \mathrm{H}\right\}$ NMR spectra were recorded at $25{ }^{\circ} \mathrm{C}$ on Bruker Avance III $600 \mathrm{MHz}$ spectrometer in deuterated solvents and were referenced to the resonances of the solvent used or external $\mathrm{SiMe}_{4}$. Microanalyses were performed by the Elemental Analysis Laboratory of the Advanced Analysis and Testing Center at Nanjing Forestry University. Melting points were determined in sealed capillaries under dinitrogen and are uncorrected. The starting materials $\operatorname{ArNH}\left(\mathrm{SiPh}_{3}\right), \operatorname{ArNH}\left(\mathrm{SiMe}_{3}\right), \mathrm{Ar}^{*} \mathrm{NH}\left(\mathrm{SiPh}_{3}\right)$ and $\operatorname{DippNH}\left(\mathrm{SiMe}_{3}\right)$ were prepared according to literature procedures. ${ }^{36,40,42}$ All other reagents were used as received.

\section{Synthesis of complex 1}

MeMgI (0.96 mL, $3 \mathrm{M}$ in $\mathrm{Et}_{2} \mathrm{O}, 2.88 \mathrm{mmol}$ ) was added dropwise to a solution of $\operatorname{ArNH}\left(\mathrm{SiPh}_{3}\right)(1.00 \mathrm{~g}, 1.44 \mathrm{mmol})$ in THF $(25 \mathrm{~mL})$ at $-60{ }^{\circ} \mathrm{C}$. The reaction mixture was warmed to room temperature and stirred overnight, filtered. Removal of the solvents gave $\mathbf{1}$ as solid which was then recrystallized from toluene and hexane to give the complex as colorless crystals at room temperature (1.02 g, yield: 88\%). $M_{\mathrm{p}}: 181-183{ }^{\circ} \mathrm{C} .{ }^{1} \mathrm{H}$ NMR $\left(600 \mathrm{MHz}, 298 \mathrm{~K}, \mathrm{C}_{6} \mathrm{D}_{6}\right.$ ): $\delta=-1.60$ (s, 3H, Mg-CH ), 0.86 (br., $4 \mathrm{H}, \mathrm{CH}_{2}$ (THF)), 1.98 (s, 3H, $\mathrm{CH}_{3}$ ), 2.60 (br., 4H, OCH $(\mathrm{THF})$ ), $6.69\left(\mathrm{~s}, 2 \mathrm{H}, \mathrm{CHPh}_{2}\right), 6.77-7.88(\mathrm{~m}, 37 \mathrm{H}, \mathrm{Ar}-\mathrm{H}) .{ }^{13} \mathrm{C}\left\{{ }^{1} \mathrm{H}\right\} \mathrm{NMR}$ (151 MHz, $\left.298 \mathrm{~K}, \mathrm{C}_{6} \mathrm{D}_{6}\right): \delta=-14.5\left(\mathrm{Mg}-\mathrm{CH}_{3}\right), 21.0\left(\mathrm{CH}_{3}\right), 24.3$ $\left(\mathrm{CH}_{2}\right.$ (THF)), $51.6\left(\mathrm{CHPh}_{2}\right), 68.4\left(\mathrm{OCH}_{2}(\mathrm{THF})\right), 125.5,128.0$, $128.8,129.3,129.8,129.9,136.1,136.6,139.8,140.6,145.5$, 145.9, $150.4(\mathrm{Ar}-C) .{ }^{29} \mathrm{Si}\left\{{ }^{1} \mathrm{H}\right\} \mathrm{NMR}\left(119 \mathrm{MHz}, 298 \mathrm{~K}, \mathrm{C}_{6} \mathrm{D}_{6}\right) \delta=$ -26.4. Anal. calc. for $\mathrm{C}_{56} \mathrm{H}_{53} \mathrm{MgNOSi}$ C, 83.20; $\mathrm{H}, 6.61 ; \mathrm{N}, 1.73$. Found: C, 83.51; H, 6.83; N, 1.41.

\section{Synthesis of complex 2}

Complex 2 was prepared using a similar procedure that employed for 1, but using $\mathrm{Ar}{ }^{*} \mathrm{NH}\left(\mathrm{SiPh}_{3}\right)$ as a starting material. Colorless crystals (yield: 90\%). $M_{\mathrm{p}}: 167-169{ }^{\circ} \mathrm{C} .{ }^{1} \mathrm{H}$ NMR $\left(600 \mathrm{MHz}, 298 \mathrm{~K}, \mathrm{C}_{6} \mathrm{D}_{6}\right.$ ): $\delta=-1.47$ (s, 3H, Mg- $\mathrm{CH}_{3}$ ), 0.83 (br., $4 \mathrm{H}, \mathrm{CH}_{2}$ (THF)), 1.00 (d, ${ }^{3} \mathrm{~J}_{\mathrm{HH}}=6.6 \mathrm{~Hz}, 6 \mathrm{H}, \mathrm{CH}\left(\mathrm{CH}_{3}\right)_{2}$ ), 2.48 (br., $4 \mathrm{H}, \mathrm{OCH}_{2}$ (THF)), $2.58\left(\mathrm{sept},{ }^{3} J_{\mathrm{HH}}=6.6 \mathrm{~Hz}, 1 \mathrm{H}, \mathrm{CH}\left(\mathrm{CH}_{3}\right)_{2}\right), 6.71$ $\left(\mathrm{s}, 2 \mathrm{H}, \mathrm{CHPh}_{2}\right), 6.80-7.88(\mathrm{~m}, 37 \mathrm{H}, \mathrm{Ar}-\mathrm{H}) .{ }^{13} \mathrm{C}\left\{{ }^{1} \mathrm{H}\right\}$ NMR (151 $\left.\mathrm{MHz}, 298 \mathrm{~K}, \mathrm{C}_{6} \mathrm{D}_{6}\right): \delta=-14.4\left(\mathrm{Mg}-\mathrm{CH}_{3}\right), 24.1\left(\mathrm{CH}\left(\mathrm{CH}_{3}\right)_{2}\right)$, 
Table 7 Crystallographic data for complexes 1-4

\begin{tabular}{|c|c|c|c|c|}
\hline & 1 & 2 & 3 & 4 \\
\hline Formula & $\mathrm{C}_{56} \mathrm{H}_{53} \mathrm{MgNOSi}$ & $\mathrm{C}_{58} \mathrm{H}_{57} \mathrm{MgNOSi}$ & $\mathrm{C}_{45} \mathrm{H}_{55} \mathrm{MgNO}_{2} \mathrm{Si}$ & $\mathrm{C}_{24} \mathrm{H}_{45} \mathrm{MgNO}_{2} \mathrm{Si}$ \\
\hline$F_{\mathrm{w}}$ & 808.39 & 836.45 & 694.30 & 432.01 \\
\hline Space group & $P 2_{1}$ & $P \overline{1}$ & $P 2_{1} / c$ & $P \overline{1}$ \\
\hline$a(\AA)$ & $10.8664(4)$ & $11.0079(6)$ & $14.9209(9)$ & $9.8194(7)$ \\
\hline$b(\AA)$ & $38.1625(15)$ & $11.3921(5)$ & $18.7056(12)$ & $16.3480(11)$ \\
\hline$\beta\left(^{\circ}\right)$ & $106.5270(10)$ & $87.559(2)$ & $93.052(2)$ & $94.112(2)$ \\
\hline$\gamma\left({ }^{\circ}\right)$ & 90 & $71.6810(10)$ & 90 & $90.371(2)$ \\
\hline$V\left(\mathrm{~A}^{3}\right)$ & $4446.3(3)$ & $2331.4(2)$ & $4006.9(4)$ & $2639.8(3)$ \\
\hline$Z$ & 4 & 2 & 4 & 4 \\
\hline$T(\mathrm{~K})$ & $135(2)$ & $135(2)$ & $135(2)$ & $135(2)$ \\
\hline$\lambda(\AA)$ & 0.71073 & 0.71073 & 0.71073 & 0.71073 \\
\hline $\mathrm{w} R_{2}$ (obsd data) & 0.0986 & 0.1525 & 0.1669 & 0.1950 \\
\hline GOF on $F^{2}$ & 1.017 & 1.197 & 1.006 & 1.119 \\
\hline
\end{tabular}

$24.2\left(\mathrm{CH}_{2}\right.$ (THF)), $33.4\left(\mathrm{CH}\left(\mathrm{CH}_{3}\right)_{2}\right), 51.6\left(\mathrm{CHPh}_{2}\right), 68.4\left(\mathrm{OCH}_{2}\right.$ (THF)), 125.5, 126.6, 127.0, 127.6, 128.0, 128.8, 129.2, 129.3, 129.6, 136.7, 139.4, 139.7, 140.3, 145.4, 146.2, $151.1(\mathrm{Ar}-C) .{ }^{29} \mathrm{Si}$ $\left\{{ }^{1} \mathrm{H}\right\} \mathrm{NMR}\left(119 \mathrm{MHz}, 298 \mathrm{~K}, \mathrm{C}_{6} \mathrm{D}_{6}\right) \delta=-26.5$. Anal. calc. for $\mathrm{C}_{58} \mathrm{H}_{57}$ MgNOSi: C, 83.28; H, 6.87; N, 1.67. Found: C, 83.61; H, $7.14 ; \mathrm{N}, 1.35$.

\section{Synthesis of complex 3}

Complex 3 was prepared using a similar procedure that employed for 1, but using $\mathrm{ArNH}\left(\mathrm{SiMe}_{3}\right)$ as a starting material. Colorless crystals (yield: 92\%). $M_{\mathrm{p}}$ : $131-133{ }^{\circ} \mathrm{C} .{ }^{1} \mathrm{H}$ NMR (600 $\left.\mathrm{MHz}, 298 \mathrm{~K}, \mathrm{C}_{6} \mathrm{D}_{6}\right): \delta=-0.79\left(\mathrm{~s}, 3 \mathrm{H}, \mathrm{Mg}-\mathrm{CH}_{3}\right), 0.25(\mathrm{~s}, 9 \mathrm{H}$, $\mathrm{Si}\left(\mathrm{CH}_{3}\right)_{3}$ ), 1.10 (br., 8H, CH (THF)), 2.07 (s, 3H, $\mathrm{CH}_{3}$ ), 3.24 (br., $8 \mathrm{H}, \mathrm{OCH}_{2}$ (THF)), 6.88 (s, 2H, CHPh ${ }_{2}$ ), 6.97-7.50 (m, 22H, Ar-H). ${ }^{13} \mathrm{C}\left\{{ }^{1} \mathrm{H}\right\}$ NMR $\left(151 \mathrm{MHz}, 298 \mathrm{~K}, \mathrm{C}_{6} \mathrm{D}_{6}\right): \delta=-12.6\left(\mathrm{Mg}-\mathrm{CH}_{3}\right), 4.6$ $\left(\mathrm{Si}\left(\mathrm{CH}_{3}\right)_{2}\right), 21.3\left(\mathrm{CH}_{3}\right), 24.9\left(\mathrm{CH}_{2}(\mathrm{THF})\right), 51.5\left(\mathrm{CHPh}_{2}\right), 69.2$ $\left(\mathrm{OCH}_{2}\right.$ (THF)), 125.9, 126.0, 126.5, 128.2, 128.3, 128.4, 128.6, $130.0,130.2,130.4,130.5,140.1,144.7,146.3,147.3(\mathrm{Ar}-C) .{ }^{29} \mathrm{Si}$ $\left\{{ }^{1} \mathrm{H}\right\} \mathrm{NMR}\left(119 \mathrm{MHz}, 298 \mathrm{~K}, \mathrm{C}_{6} \mathrm{D}_{6}\right): \delta=-8.09$. Anal. calc. for $\mathrm{C}_{45} \mathrm{H}_{55} \mathrm{MgNO}_{2} \mathrm{Si}: \mathrm{C}, 77.84 ; \mathrm{H}, 7.98 ; \mathrm{N}, 2.02$. Found: C, 78.16; H, 8.32; N, 1.73 .

\section{Synthesis of complex 4}

Complex 4 was prepared using a similar procedure that employed for $\mathbf{1}$, but using $\mathrm{DippNH}\left(\mathrm{SiMe}_{3}\right)$ as a starting material. Colorless crystals (yield: $91 \%) . M_{\mathrm{p}}$ : $90-92{ }^{\circ} \mathrm{C} .{ }^{1} \mathrm{H} \mathrm{NMR}(600 \mathrm{MHz}$, $\left.298 \mathrm{~K}, \mathrm{C}_{6} \mathrm{D}_{6}\right): \delta=-0.94\left(\mathrm{~s}, 3 \mathrm{H}, \mathrm{Mg}-\mathrm{CH}_{3}\right), 0.38\left(\mathrm{~s}, 9 \mathrm{H}, \mathrm{Si}\left(\mathrm{CH}_{3}\right)_{3}\right)$, 1.18 (br., 8H, $\mathrm{CH}_{2}$ (THF)), 1.25 (d, ${ }^{3} J_{\mathrm{HH}}=6.6 \mathrm{~Hz}, 6 \mathrm{H}, \mathrm{CH}\left(\mathrm{CH}_{3}\right)_{2}$ ), $1.42\left(\mathrm{~d},{ }^{3} \mathrm{~J}_{\mathrm{HH}}=6.6 \mathrm{~Hz}, 6 \mathrm{H}, \mathrm{CH}\left(\mathrm{CH}_{3}\right)_{2}\right), 3.32$ (br., 8H, $\mathrm{CH}_{2}$ (THF)), 4.22 (sept, 2H, CH( $\left.\left.\mathrm{CH}_{3}\right)_{2}\right), 6.96\left(\mathrm{t},{ }^{3} J_{\mathrm{HH}}=7.2 \mathrm{~Hz}, 1 \mathrm{H}, \mathrm{Ph}-H\right), 7.14$ $\left(\mathrm{d},{ }^{3} \mathrm{~J}_{\mathrm{HH}}=7.2 \mathrm{~Hz}, 2 \mathrm{H}, \mathrm{Ph}-H\right) .{ }^{13} \mathrm{C}\left\{{ }^{1} \mathrm{H}\right\} \mathrm{NMR}(151 \mathrm{MHz}, 298 \mathrm{~K}$, $\left.\mathrm{C}_{6} \mathrm{D}_{6}\right): \delta=-15.0\left(\mathrm{Mg}-\mathrm{CH}_{3}\right), 3.4\left(\mathrm{Si}\left(\mathrm{CH}_{3}\right)_{3}\right), 24.7\left(\mathrm{CH}_{2}\right.$ (THF)), $24.9\left(\mathrm{CH}\left(\mathrm{CH}_{3}\right)_{2}\right), 25.2\left(\mathrm{CH}\left(\mathrm{CH}_{3}\right)_{2}\right), 26.8\left(\mathrm{CH}\left(\mathrm{CH}_{3}\right)_{2}\right), 68.4\left(\mathrm{OCH}_{2}\right.$ (THF)), 118.9, 122.9, 144.8, $152.6 \quad(\mathrm{Ar}-\mathrm{C}) .{ }^{29} \mathrm{Si}\left\{{ }^{1} \mathrm{H}\right\} \quad \mathrm{NMR}$
(119 MHz, $298 \mathrm{~K}, \mathrm{C}_{6} \mathrm{D}_{6}$ ): $\delta=-8.14$. Anal. calc. for $\mathrm{C}_{24} \mathrm{H}_{45^{-}}$ $\mathrm{MgNO}_{2} \mathrm{Si}: \mathrm{C}, 66.72 ; \mathrm{H}, 10.50 ; \mathrm{N}, 3.24$. Found: C, 66.95; H, $10.76 ; \mathrm{N}, 2.94$.

\section{X-ray crystal structure determination}

Crystallographic data for complexes 1-4 are given in Table 7. Diffraction data were collected on a Bruker D8 VENTURE PHOTON 100 diffractometer using a graphite-monochromated MoK $\alpha$ radiation $(0.71073 \AA)$ at $135 \mathrm{~K}$ in the $\omega$ - $2 \theta$ scan mode. In all cases, an empirical absorption correction by SADABS was applied to the intensity data. The structures were solved by direct methods and refined on $F^{2}$ by full-matrix least-squares methods using the SHELXTL crystallographic software package. All non-hydrogen atoms were refined anisotropically with hydrogen atoms included in calculated positions (riding model). CCDC 1554843-1554846 contain the supplementary crystallographic data for complexes 1-4. $\dagger$

\section{General procedure for catalytic hydroboration of ketones}

In a glove box, catalyst $4(0.1 \mathrm{~mol} \%)$ was added to a solution of ketone $(1 \mathrm{mmol})$ and pinacolborane $(1.5 \mathrm{mmol})$ in a J. Young NMR tube equipped with a Teflon screw cap, which was charged with $\mathrm{C}_{6} \mathrm{D}_{6}(0.5 \mathrm{~mL})$. The progress of the reaction was monitored by ${ }^{1} \mathrm{H}$ NMR and ${ }^{11} \mathrm{~B}$ NMR, which indicated the completion of the reaction by the appearance of a new $\mathrm{CH}$ resonance.

\section{Conflicts of interest}

There are no conflicts of interest to declare.

\section{Acknowledgements}

We thank the National Natural Science Foundation of China (Grant No. 21372117, 21772093) and the Natural Science 
Foundation of Jiangsu Province, China (Grant No. BK20141468) for support of this research.

\section{References}

1 K. Revunova and G. I. Nikonov, Dalton Trans., 2015, 44, 840.

2 C. C. Chong and R. Kinjo, ACS Catal., 2015, 5, 3238.

3 S. J. Geier, C. M. Vogels and S. A. Westcott, ACS Symp. Ser., 2016, 1236, 209.

4 M. S. Hill, D. J. Liptrot and C. Weetman, Chem. Soc. Rev., 2016, 45, 972.

5 M. Arrowsmith, Encycl. Inorg. Bioinorg. Chem., 2016, p. 1.

6 W. Li, X. Ma, M. G. Walawalkar, Z. Yang and H. W. Roesky, Coord. Chem. Rev., 2017, DOI: 10.1016/j.ccr.2017.03.017.

7 J. H. Docherty, J. Peng, A. P. Dominey and S. P. Thomas, Nat. Chem., 2017, 9, 595.

8 S. Chakrabarty and J. M. Takacs, J. Am. Chem. Soc., 2017, 139, 6066.

9 S. Yu, C. Wu and S. Ge, J. Am. Chem. Soc., 2017, 139, 6526.

10 R. Shintani and K. Nozaki, Organometallics, 2013, 32, 2459.

11 T. J. Hadlington, C. E. Kefalidis, L. Maron and C. Jones, ACS Catal., 2017, 7, 1853.

12 V. L. Weidner, C. J. Barger, M. Delferro, T. L. Lohr and T. J. Marks, ACS Catal., 2017, 7, 1244.

13 S. Chen, D. Yan, M. Xue, Y. Hong, Y. Yao and Q. Shen, Org. Lett., 2017, 19, 3382.

14 V. Vasilenko, C. K. Blasius, H. Wadepohl and L. H. Gade, Angew. Chem., Int. Ed., 2017, 56, 8393.

15 R. Arévalo, C. M. Vogels, G. A. MacNeil, L. Riera, J. Péreza and S. A. Westcott, Dalton Trans., 2017, 46, 7750.

16 T. J. Hadlington, M. Hermann, G. Frenking and C. Jones, J. Am. Chem. Soc., 2014, 136, 3028.

17 C. C. Chong, H. Hirao and R. Kinjo, Angew. Chem., Int. Ed., 2015, 54, 190.

18 D. Mukherjee, H. Osseili, T. P. Spaniol and J. Okuda, J. Am. Chem. Soc., 2016, 138, 10790.

19 H. Osseili, D. Mukherjee, K. Beckerle, T. P. Spaniol and J. Okuda, Organometallics, 2017, DOI: 10.1021/ acs.organomet.7b00308.

20 Z. Yang, M. Zhong, X. Ma, S. De, C. Anusha, P. Parameswaran and H. W. Roesky, Angew. Chem., Int. Ed., 2015, 54, 10225.

21 V. K. Jakhar, M. K. Barman and S. Nembenna, Org. Lett., 2016, 18, 4710.

22 Y. Wu, C. Shan, Y. Sun, P. Chen, J. Ying, J. Zhu, L. Liu and Y. Zhao, Chem. Commun., 2016, 52, 13799.

23 M. K. Bisai, S. Pahar, T. Das, K. Vanka and S. S. Sen, Dalton Trans., 2017, 46, 2420.

24 S. Yadav, S. Pahar and S. S. Sen, Chem. Commun., 2017, 53, 4562.

25 J. Schneider, C. P. Sindlinger, S. M. Freitag, H. Schubert and L. Wesemann, Angew. Chem., Int. Ed., 2017, 56, 333.
26 D. Wu, R. Wang, Y. Li, R. Ganguly, H. Hirao and R. Kinjo, Chem, 2017, 3, 134.

27 Y. Wu, C. Shan, J. Ying, J. Su, J. Zhu, L. L. Liu and Y. Zhao, Green Chem., 2017, DOI: 10.1039/c7gc01632h.

28 R. Rochat, M. J. Lopez, H. Tsurugi and K. Mashima, ChemCatChem, 2016, 8, 10.

29 (a) M. Arrowsmith, M. S. Hill, T. Hadlington, G. Kociok-Köhn and C. Weetman, Organometallics, 2011, 30, 555; (b) C. Weetman, M. S. Hill and M. F. Mahon, Polyhedron, 2016, 103, 115; (c) M. Arrowsmith, T. J. Hadlington, M. S. Hill and G. Kociok-Köhn, Chem. Commun., 2012, 48, 4567; (d) M. Arrowsmith, M. S. Hill and G. Kociok-Köhn, Chem.-Eur. J., 2013, 19, 2776; (e) C. Weetman, M. S. Hill and M. F. Mahon, Chem. Commun., 2015, 51, 14477; $(f)$ C. Weetman, M. D. Anker, M. Arrowsmith, M. S. Hill, G. Kociok-Köhn, D. J. Liptrot and M. F. Mahon, Chem. Sci., 2016, 7, 628; (g) C. Weetman, M. S. Hill and M. F. Mahon, Chem.-Eur. J., 2016, 22, 7158; (h) Y. Yang, M. D. Anker, J. Fang, M. F. Mahon, L. Maron, B. Weetman and M. S. Hill, Chem. Sci., 2017, 8, 3529; (i) M. D. Anker, M. S. Hill, J. P. Lowe and M. F. Mahon, Angew. Chem., Int. Ed., 2015, 54, 10009; (j) M. D. Anker, C. E. Kefalidis, Y. Yang, J. Fang, M. S. Hill, M. F. Mahon and L. Maron, J. Am. Chem. Soc., 2017, 139, 10036.

30 J. Intemann, M. Lutz and S. Harder, Organometallics, 2014, 33, 5722 .

31 (a) D. Mukherjee, A. Ellern and A. D. Sadow, Chem. Sci., 2014, 5, 959; (b) N. L. Lampland, M. Hovey, D. Mukherjee and A. D. Sadow, ACS Catal., 2015, 5, 4219.

32 D. Mukherjee, S. Shirase, T. P. Spaniol, K. Mashimab and J. Okuda, Chem. Commun., 2016, 52, 13155.

33 L. Fohlmeister and A. Stasch, Chem.-Eur. J., 2016, 22, 10235.

34 K. Manna, P. Ji, F. X. Greene and W. Lin, J. Am. Chem. Soc., 2016, 138, 7488.

35 M. K. Barman, A. Baishya and S. Nembenna, Dalton Trans., 2017, 46, 4152.

36 A. J. Boutland, D. Dange, A. Stasch, L. Maron and C. Jones, Angew. Chem., Int. Ed., 2016, 55, 9239.

37 P. J. Bailey, C. M. E. Dick, S. Fabre and S. Parsons, J. Chem. Soc., Dalton Trans., 2000, 1655.

38 M. R. Crimmin, M. Arrowsmith, A. G. M. Barrett, I. J. Casely, M. S. Hill and P. A. Procopiou, J. Am. Chem. Soc., 2009, 131, 9670.

39 J. F. Dunne, D. B. Fulton, A. Ellern and A. D. Sadow, J. Am. Chem. Soc., 2010, 132, 17680.

40 J. Li, A. Stasch, C. Schenk and C. Jones, Dalton Trans., 2011, 40, 10448.

41 D. J. Liptrot, M. S. Hill, M. F. Mahon and A. S. S. Wilson, Angew. Chem., Int. Ed., 2015, 54, 13362.

42 Y. W. Chao, P. A. Wexler and D. E. Wigley, Inorg. Chem., 1989, 28, 3860 . 